\title{
NADP-Dependent Malic Enzyme
}

National Cancer Institute

\section{Source}

National Cancer Institute. NADP-Dependent Malic Enzyme. NCI Thesaurus. Code C127141.

NADP-dependent malic enzyme (572 aa, $64 \mathrm{kDa}$ ) is encoded by the human ME1 gene.

This protein plays a role in the oxidative decarboxylation of malate. 